\title{
SPECTRUM OF EXFOLIATIVE CYTOLOGY AT BIRAT MEDICAL COLLEGE TEACHING HOSPITAL
}

\author{
Shaukin $\mathrm{S}^{1^{*}}$, Kafle $S U^{2}$, Singh $\mathrm{M}^{3}$
}

\begin{abstract}
Affiliation
1. Lecturer, Department of Pathology, Birat Medical College Teaching hospital.

2. Assosicate Professor and HOD, Department of Pathology, Birat Medical College Teaching hospital.

3. Assistant Professor, Department of Pathology, Birat Medical College Teaching hospital.
\end{abstract}

\section{ARTICLE INFO}

$\begin{array}{ll}\text { Received } & 02 \text { July, } 2019 \\ \text { Accepted } & 11 \text { August, } 2019 \\ \text { Published : } & 31 \text { August, } 2019\end{array}$

(C) Authors retain copyright and grant the journal right of first publication with the work simultaneously licensed under Creative Commons Attribution License CC - BY 4.0 that allows others to share the work with an acknowledgment of the work's authorship and initial publication in this journal.

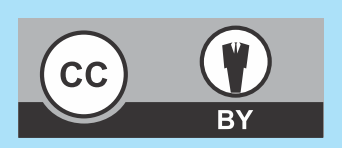

ORA 123

DOI: http://dx.doi.org/10.3126/bjhs.v4i2.25456

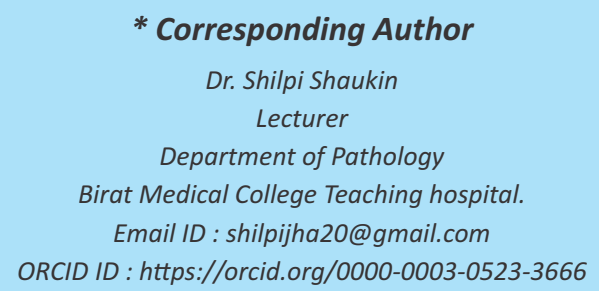

\section{Citation}

Shaukin S, Kafle SU, Singh M. Spectrum of Exfoliative Cytology at Birat Medical College Teaching Hospital. BJHS 2019;4(2)9: 734 - 737.

\section{ABSTRACT}

\section{Introduction}

Exfoliative cytological study of body fluids is easy, simple, rapid, cost effective and patient compliant investigation that helps in characterizing the disease into their varying subtypes. These presumptive and sometimes definitive diagnoses are in most cases the cornerstone which helps in staging and prognosis of the patient

\section{Objective}

To determine the spectrum of malignant and non-malignant lesions in exfoliative cytology

\section{Methodology}

This was a quantitative retrospective cross sectional study conducted at Birat Medical College Teaching Hospital from $24^{\text {th }}$ December 2014 to $24^{\text {th }}$ December 2018. All the exfoliative samples received at the lab were accepted in our study.

\section{Results}

Of the 300 samples received, the maximum number were those of sputum followed by pleural fluid and ascitic fluid. Peritoneal fluid, Cerebrospinal fluid, synovial fluid, fluid from suspected abscess and breast fluid were also received. Malignancy was found in $1.67 \%$ of the samples studies.

\section{Conclusion}

A study of different cytomorphological features of exfoliative cytology samples will help in establishing the role of cytology as an important diagnostic tool in improving the effectiveness of diagnosis, treatment \& prognosis of the patient in the medical field.

\section{KEY WORD}

Body fluids, cytology, malignant effusions 


\section{INTRODUCTION}

Historically the origins of cytology can be tracked back to the early $500 \mathrm{BC}$, when the first reports on visual morphological diagnosis during autopsy were compiled. ${ }^{1}$ The invention of the microscope by Hans and his son, Zacharias Janssen, ushered in the era of microscopic examination and diagnosis. ${ }^{2}$ German physiologist Johannes Peter Muller is considered to be the father of medical microscopy. He was the first to establish microscopic criteria for the differential diagnosis between benign and malignant neoplasms. ${ }^{3}$ Kun attempted for the first time to use a needle for diagnosing tumor in $1846 .{ }^{4}$ In 1853 the first micrsocopic examination of cells sampled via needle aspiration from breast tissue was conducted by Paget. ${ }^{5}$ In 1921 at the John Hopkins Hospital in Baltimore Guthrie started the use of air-dried films with Romanowsky staining. ${ }^{6}$

Malignant cells in sputum were observed for the first time in 1843 by Walter Hayle Walshe. ${ }^{7}$ Later in 1846 he illustrated cancer cells in sputum of a patient with lung cancer and in the vomitus of another patient with gastric cancer. ${ }^{8}$ Hampeln, in 1887, published the first case of primary carcinoma of the lung and pleura with an illustration of a drawing of cancer cells. ${ }^{9}$ In 1935, Dudgeon and Wrigley established the cytological examination of sputum for the diagnosis of cases with lung cancer. ${ }^{10,11}$ Quincke studied the properties of chylous fluids numerating the difficulties of examining such material. ${ }^{12}$ An important advance in cytology was the use of air drained films by Paul Ehrlich in the identification of malignant cells not only in blood but also in various serous effusions. ${ }^{13}$ The discovery of lumbar puncture by Quincke in 1891 inaugurated the cytologic study of CSF. ${ }^{14}$ Widal and Ravaut in 1900 employed Romanowsky dyes in analyzing cytological preparations from pleural fluids. ${ }^{15,16}$

From those humble beginnings cytological analysis today has become an indispensible pillar of modern medicine. This simple, rapid, cost effective and patient compliant investigation from various body fluids helps us in characterizing the disease into their varying subtypes. These presumptive and sometimes definitive diagnoses are in most cases the cornerstone which dictates the management plan of the patient. The cytological and physical examination by pathologists not only helps to ascertain the etiological agent but also helps in understanding the disease process and monitoring response to treatment. ${ }^{17}$

Body cavities bounded by epithelial lining maintain a minimum amount of fluid. The collection of excess amounts of fluids in these chambers are due to disproportionate formation and/or removal as governed by starlings law. ${ }^{18}$ The various causes leading to effusions include infection, inflammation and malignancy. The major body fluids examined include those from the peritoneal, pleural, synovial, cerebrospinal and pericardial spaces. ${ }^{19}$

\section{METHODOLOGY}

This was a quantitative retrospective cross sectional study conducted at Birat Medical College Teaching Hospital from $24^{\text {th }}$ December 2014 to $24^{\text {th }}$ December 2018. All the exfoliative samples received at the lab were accepted in our study. Urine samples were excluded from this study. All the samples were processed in a $3000 \mathrm{rpm}$ centrifuge for five minutes. Following which 4 smears were prepared, 2 each were stained with Papanicoulau and Giemsa respectively. Each of the slides was examined by a minimum of two pathologists and then a conclusion was drawn. Data was collected and tabulated by using Microsoft Excel sheet and SPSS.

\section{RESULTS}

Of the 300 cases studied $57.3 \%$ were male and $42.7 \%$ were female as shown in table 1.

\begin{tabular}{lcc}
\multicolumn{3}{c}{ Table $1:$ Frequency of gender distribution } \\
Gender & Number & Percent \\
Male & 172 & 57.33 \\
Female & 128 & 42.67 \\
Total & 300 & 100
\end{tabular}

Table 2 : Distribution of various types of samples received

$\begin{array}{lcc}\text { Sample } & \text { Number } & \text { Percent } \\ \text { Sputum } & 184 & 61.33 \\ \text { Pleural } & 53 & 17.67 \\ \text { Ascitic } & 41 & 13.67 \\ \text { Peritoneal } & 7 & 2.33 \\ \text { CSF } & 6 & 2.00 \\ \text { Synovial fluid } & 4 & 1.33 \\ \text { Abscess } & 4 & 1.33 \\ \text { Breast } & 1 & 0.33 \\ \text { Total } & 300 & 100\end{array}$

The gender distribution in accordance to each sample type is expressed in table 3.

\begin{tabular}{|c|c|c|c|c|c|c|c|c|c|}
\hline Sex & Sputum & Pleural & Ascitic & Peritoneal & CSF & Synovial & Abscess & Breast & Total \\
\hline Male & 105 & 34 & 21 & 3 & 4 & 3 & 2 & 0 & 172 \\
\hline Female & 79 & 19 & 20 & 4 & 2 & 1 & 2 & 1 & 128 \\
\hline Total & 184 & 53 & 41 & 7 & 6 & 4 & 4 & 1 & 300 \\
\hline
\end{tabular}

On categorizing the samples on the basis of their age groups maximum cases belonged to the age group of 70 to 80 years. These were 74 cases comprising $24.67 \%$ of the total sample size. Ages ranged from a 4 day old child up to 95 years. Mean age of the study population is 57.8 years with a median age of 62 years and a standard deviation of 18.61. Samples and their frequency in each age group are shown in the table 4 below.

Table 4 : Distribution of different types of specimen according to age group

$\begin{array}{lcccccccccc}\text { Age } & \text { Sputum } & \text { Pleural } & \text { Ascitic } & \text { Peritoneal } & \text { CSF } & \text { Synovial } & \text { Pus } & \text { Breast } & \text { Total } & \text { Percent } \\ 0-10 & 0 & 0 & 0 & 0 & 1 & 0 & 1 & 0 & 2 & 0.67 \\ 10-20 & 3 & 2 & 1 & 0 & 1 & 0 & 1 & 0 & 8 & 2.67 \\ 20-30 & 5 & 5 & 3 & 0 & 1 & 2 & 0 & 0 & 16 & 5.33 \\ 30-40 & 6 & 5 & 13 & 1 & 0 & 2 & 0 & 1 & 28 & 9.33 \\ 40-50 & 19 & 5 & 7 & 4 & 0 & 0 & 0 & 0 & 35 & 11.67 \\ 50-60 & 21 & 12 & 5 & 2 & 2 & 0 & 1 & 0 & 43 & 14.33 \\ 60-70 & 56 & 6 & 5 & 0 & 0 & 0 & 0 & 0 & 67 & 22.33 \\ 70-80 & 53 & 16 & 4 & 0 & 1 & 0 & 0 & 0 & 74 & 24.67 \\ 80-90 & 19 & 2 & 1 & 0 & 0 & 0 & 1 & 0 & 23 & 7.67 \\ 90-100 & 2 & 0 & 2 & 0 & 0 & 0 & 0 & 0 & 4 & 1.33 \\ \text { Total } & 184 & 53 & 41 & 7 & 6 & 4 & 4 & 1 & 300 & \end{array}$


Sputum: The diagnosis of the sputum samples were classified into benign and suspicious. In benign category it was subdivided into 174 descriptive cases, 4 fungal, 2 reactive and one each inflammatory and lymphocytic. The remaining 2 were in the suspicious category as shown in table 5.

$\begin{array}{lcc}\begin{array}{l}\text { Table 5: Categorization of the sputum samples } \\ \text { Sputum Diagnosis }\end{array} & \text { Number } & \text { Percentage } \\ \text { Descriptive } & 174 & 94.56 \\ \text { Fungal } & 4 & 2.17 \\ \text { Reactive } & 2 & 1.09 \\ \text { Suspicious } & 2 & 1.09 \\ \text { Inflammatory } & 1 & 0.54 \\ \text { Lymphocytic } & 1 & 0.54\end{array}$

Pleural fluid: Samples were examined under microscope and classified as Benign, Malignant and Metastatic adenocarcinomas. Under benign a subcategorisation was done into Descriptive, Lymphocytic, Inflammatory, Reactive, Neutrophilic as shown in table 6.

$\begin{array}{lcc}\text { Table 6 : Categorization of the pleural fluid samples } \\ \text { Pleural fluid Diagnosis } & \text { Number } & \text { Percentage } \\ \text { Descriptive } & 23 & 43.39 \\ \text { Lymphocytic } & 12 & 22.64 \\ \text { Inflammatory } & 10 & 18.87 \\ \text { Reactive } & 3 & 5.67 \\ \text { Malignant } & 2 & 3.77 \\ \text { Neutrophillic } & 2 & 3.77 \\ \text { Mets adeno } & 1 & 1.89 \\ \text { Total } & 53 & 100\end{array}$

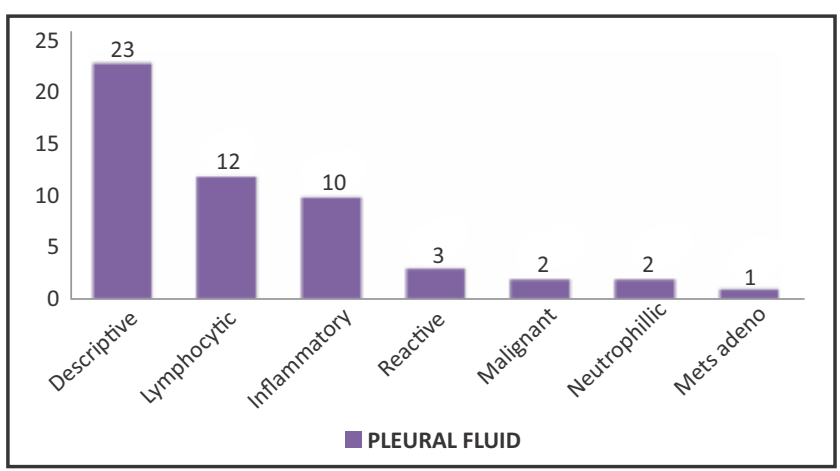

Figure 1: Spectrum of diagnosis in pleural fluid samples

Ascitic fluid: The ascitic fluid samples on analysis were found to be benign in most cases which were further classified into descriptive, inflammatory, lymphocytic and reactive. Other diagnosis obtained ten, metastatic adenocarcinoma as represented in table 7 .

$\begin{array}{lcc}\begin{array}{l}\text { Table 7: Categorization of ascitic fluid samples } \\ \text { Ascitic fluid Diagnosis }\end{array} & \begin{array}{l}\text { Number } \\ \text { Percent }\end{array} \\ \text { Descriptive } & 30 & 73.17 \\ \text { Inflammatory } & 6 & 14.63 \\ \text { Lymphocytic } & 2 & 4.88 \\ \text { Mets adeno } & 1 & 2.43 \\ \text { Reactive } & 2 & 4.88\end{array}$

Others: All 7 of the peritoneal fluid samples were benign, 5 of these were descriptive, while 1 sample each was categorized as hemorrhagic and inflammatory. Of the 6 CSF samples 3 were lymphocytic, 2 descriptive and 1 inflammatory. Fluid obtained from 4 suspected abscess lesions showed suppuration in 3 of them while 1 was inflammatory. Synovial fluid on analysis showed 3 inflammatory samples and 1 infective. The single Breast fluid sample obtained was malignant.

The total number of samples with a diagnosis of malignancy was five. There were two sputum samples which were reported as to be suspicious of malignancy. Of all the five malignant samples two were pleural fluid samples and 1 was the breast fluid sample. The remaining two were metastatic adenocarcinomas seen in one ascitic fluid and one pleural fluid respectively.

\begin{tabular}{|c|c|c|c|c|c|}
\hline & $\begin{array}{l}\text { Khatib } \\
\text { et al }\end{array}$ & $\begin{array}{l}\text { Gupta } \\
\text { et al }\end{array}$ & $\begin{array}{l}\text { Maharjan } \\
\text { et al }\end{array}$ & $\begin{array}{l}\text { Shrestha } \\
\text { et al }\end{array}$ & $\begin{array}{l}\text { Pradhan } \\
\text { et al }\end{array}$ \\
\hline Number of samples & 414 & 185 & 1129 & 385 & 584 \\
\hline Sex ratio & $1: 1$ & $1.6: 1$ & $1.33: 1$ & $1.56: 1$ & NA \\
\hline $\begin{array}{l}\text { Most common age } \\
\text { group }\end{array}$ & $40-50$ & $30-40$ & $50-59$ & $31-40$ & NA \\
\hline Most common sample & $\begin{array}{l}\text { Periton } \\
\text { eal }\end{array}$ & $\begin{array}{l}\text { Periton } \\
\text { eal }\end{array}$ & Pleural & Peritoneal & Peritoneal \\
\hline Malignancy reported & $7.48 \%$ & $5.4 \%$ & $5.8 \%$ & $2.59 \%$ & $18.66 \%$ \\
\hline $\begin{array}{l}\text { Malignancy in } \\
\text { pleural fluid }\end{array}$ & $9.42 \%$ & $5.47 \%$ & $3.8 \%$ & $6.38 \%$ & $19.64 \%$ \\
\hline $\begin{array}{l}\text { Malignancy in } \\
\text { Ascitic Fluid }\end{array}$ & $9.52 \%$ & $5.43 \%$ & $5.8 \%$ & $2.29 \%$ & $18.8 \%$ \\
\hline
\end{tabular}

\section{DISCUSSION}

We studied a total of 300 cases, over 60 percent of which were sputum samples. The male to female ratio in our study was 1.34 which is comparable with other similar studies. ${ }^{20-24}$ The cases were most in the 70 to 80 age group (24.67\%). 109 of the 184 sputum samples were patients in their seventh to eighth decades.

Of the aspirated samples pleural aspirates $(17.67 \%)$ were the most in number followed closely by ascitic fluid (13.67\%) and peritoneal wash $(2.33 \%)$. Peritoneal fluid and pleural fluids form the most common samples as examined by other authors. $^{20-24}$

Malignancy was reported in $1.67 \%$ of all the samples we studied. 3 of these were pleural fluid samples while 1 each was from an ascitic tap and breast fluid. Of the 5 cases, 2 were metastatic adenocarcinoma while the others could not be characterized. The percentage of malignancy in other studies range from $2.59 \%$ to $18.66 \%{ }^{20-24}$ Similar data were reported by other studies where the most commonly diagnosed malignancy was Adenocarcinoma and the sample were mostly obtained from either the peritoneal or pleural fluid. ${ }^{20-24}$ Two of our samples of sputum were suspicious of malignancy. In these two cases further imaging and image guided biopsy were advised.

A total of $5.66 \%$ of pleural fluid and $2.43 \%$ of ascitic fluid samples were shown to be malignant .Pleural fluid samples showed malignancy rates from $3.8 \%$ to a maximum of 
$19.64 \%{ }^{20-24}$ Ascitic fluid analysis in other studies showed malignancy percentages ranging from $2.29 \%$ to $18.8 \%{ }^{20-24}$

CSF formed $2 \%$ of our total sample case which was similar to other studies. ${ }^{20,23,24}$ Khatib et al and Shulbha et al had a higher number of CSF samples, $15.4 \%$ and $25.97 \%$ respectively. ${ }^{21,22}$ None of these studies showed malignancy which was similar to our study.

Synovial fluid samples were $1.33 \%$ of our sample size, simialr to other studies. ${ }^{20-22,24}$ Gupta et al showed a higher percentage of synovial fluid samples $6.4 \%{ }^{23} 75 \%$ of our synovial samples were inflammatory as corroborated in his study by Ostovicetal ${ }^{26}$. We found no malignancy in our synovial fluid analysis as was the case in the other studies which is in keeping with the nature of tumor cells to rarely infiltrate the joint. ${ }^{26}$ The findings of other similar studies on exfoliative samples are shown in the table 8.

\section{CONCLUSION}

Exfoliative cytology should be suggested in all cases of effusion and suspected malignancies which helps in reaching at a particular diagnosis and aids in further management. Besides these tests, application of cytospin and applying tumor markers to these exfoliative samples can further increase the gamut of these tests.

Limitations of the study: Lack of Cytospin Slides Lack of special stains

\section{ACKNOWLEDGEMENT}

We would like to acknowledge Dr. Surya Parajuli for his technical assistance.

\section{CONFLICT OF INTEREST}

None declared

\section{FINANCIALDISCLOSURE}

No funding sources

\section{ETHICAL APPROVAL}

The study was approved by the Institutional Review Committee, Birat medical college

\section{REFERENCES}

1. Underwood JCE. Introduction to Pathology. Part I: General and Systematic Pathology. Edinburgh: Churchil Livingstone; 2004. p 4. Doi $=\{10.1002 /$ dc.22887 $\}$

2. Hajdu SI. Cytology from antiquity to Papanicolaou. ActaCytol 1977;21:668-676.PMID:341630

3. Haggard HW. The conception of cancer before and after Johannes Muller. Bull NY Acad Med 1938;14:183-197.PMID: 19312055

4. Kun M. A new instrument for the diagnosis of tumors. Month J Med Sci $1847 ; 7: 853-854$. doi $=\{10.1002 / d c .22887\}$

5. Paget J. Lectures on Tumors. London: Longman; 1853.doi $=$ $\{10.1002 / d c .22887\}$

6. Guthrie C. Gland puncture as a diagnostic measure. Bull Johns Hopkins Hospital 1921;32:266-269.

7. George Nicholas Papanicolaou (1883-1962). CA Cancer J Clin $1973 ; 23: 171-173 \cdot d o i=\{10 \cdot 1002 / d c .22887\}$

8. Walshe W. The Nature and Treatment of Cancer. London Taylor and Walton; 1846.https://archive.org/details/b21307659/page

9. Hampeln P. U" bereinen Fall von prima"renLungen-Pleura-Carinom. St. Petersburg med Wohenschr 1887;12:137.Doi $=\{10.1002$ / dc.22887\}

10. Dudgeon $L S$, Barrett $N$. The examination of fresh tissues by the wetfilm method. Br J Surg 1934;22:4-22..https://doi.org/10.1002/ bjs. 1800228503

11. Dudgeon LS, Patrick SV. A new method for the rapid microscopical diagnosis of tumours: with an account of 200 cases so examined. $\mathrm{Br} \mathrm{J}$ Surg 1927;15:250-261.https://doi.org/10.1002/bjs.1800155810

12. Quincke H. U* berfetthaltigeTranssudate: HydropsChylosus and HydropsAdiposus. Dtsch Arch Klin Med 1875;16:121-139.doi $=\{10$. $1002 / d c .22887\}$

13. Ehlrich P. Beitra"gezur $A$ " tiologie und Histologiepleuritischer Exsudate. Charite'-Annalen 1882;7:199-230.doi $=\{10.1002 /$ dc.22887\}

14. Quincke H.U" ber Hydrocephalus, Verhandlungen des Congressus fur innereMedizin, Vol10. Wiesbaden: JF Bergman; 1891. doi $=\{10.1002 /$ dc.22887\}

15. Widal F, Ravaut P. Applications cliniques de l'e'tudehistologique des e'panchementsse'ro-fibrineux de la ple vre. C R SocBiol 1900; $52: 648,651,653$. doi $=\{10.1002 / d c .22887\}$

16. Widal F, Sicard JA, Ravaut P. A propos du cytodiagnostic du tabes. Rev Neurol 1903;11:289-292.doi $=\{10.1002 / d c .22887\}$

17. EnaDowerah, Sandip Das. Cytological evaluation of peritoneal fluid with special reference to malignancy. International Journal of Biomedical Research. 2014;5(6):396-399DOI: https://doi.org/ 10.7439/ijbr.v5i6.668

18. Kumavat PV, Kulkarni MP, Sulhyan KR. Cytological study of effusions. Indian Medical Gazette.2013;August:306-313. http://medind.nic.in/ ice/t13/i8/icet13i8p306.pdf

19. Nguyen G. Essentials of fluid cytology.2009:9-71. https://pathology. ubc.ca/files/2012/06/FLUIDCYTOLOGYBook09R1.pdf

20. Maharjan, S., Ranabhat, S., Tiwari, M., Bhandari, A., Osti, B., \& Neopane, P. (2017). Exfoliative cytology analysis from different sites of the body. Journal of Chitwan Medical College, 7(2), 33-39. https://doi.org/10.3126/jcmc.v7i2.23674

21. Khatib M W , Patel M P, Demde B R, Aher C V. Exfoliative cytology of body fluids: an analysis. Asian Pac. J. Health Sci., 2016; 3 (4):117-119. doi: 10.21276/apjhs.2016.3.4.18

22. Shulbha V S, Dayananda B S. Cytology of body fluids - an aid to primary diagnosis. Indian Journal of Pathology and Oncology, AprilJune 2015;2(2);81-83 https://pdfs.semanticscholar.org/50ca/ ff87db1a478b8a745bc06ee277e1ebd7cdb9.pdf

23. Gupta R, Dewan D, Raina R, Gupta M. Exfoliative cytology of body fluids: a study from provincial hospital of Gupta et al region, India. Int J Res Med Sci 2016;4:1016-9. DOI: http://dx.doi.org/10.18203/ 2320-6012.ijrms20160720

24. Pradhan S B, Pradhan B, Dali S Cytology of body fluids from different sites: An approach for early diagnosis of malignancy J Nep Med Assoc 2006; 45: 353-356 PMID: 17676071

25. Ostović KT, Kaić G, Ostović I, Skoro M, Novak NP, Morović-Vergles J. The importance of urgent cytological examination of synovial fluids in differentiation inflammatory and noninflammatory joint diseases. CollAntropol 2010;34(1):145-52.PMID:20432743 